\title{
INVESTIGATION AND MODELING OF TRANSPORT NOISE DEPENDENCE ON TRAFFIC SPEED AND IMPACT ON POPULATION ANNOYANCE
}

\author{
Tomas VILNIŠKIS ${ }^{1}$, Andrej NAIMUŠIN ${ }^{2 *}$, Tomas JANUŠEVIČIUS ${ }^{1,2}$ \\ ${ }^{1}$ Environmental Protection and Water Engineering Department, \\ Vilniaus Gediminas Technical University, Vilnius, Lithuania \\ ${ }^{2}$ Research Institute of Environmental Protection, Vilniaus Gediminas Technical University, Vilnius, Lithuania
}

Received 08 April 2021; accepted 18 June 2021

\section{Highlights}

Based on the results obtained, vehicle engines make the biggest impact on noise at a traffic flow rate of $30 \mathrm{~km} / \mathrm{h}$ which decreases along with an increase in speed. At a traffic flow rate of $60 \mathrm{~km} / \mathrm{h}$, noise spread is caused by vehicle aerodynamics and tire noise.

$>$ The completed simulation demonstrated that an increasing traffic flow rate lead to a drop in engine-produced noise thus decreasing environmental noise and the annoyance level.

The obtained results show that the noise level is sufficiently high under a traffic flow rate of $30 \mathrm{~km} / \mathrm{h}$. In contrast to the assumptions made before studies, a rise in traffic flow decreases the noise level that is lower at 40 and $50 \mathrm{~km} / \mathrm{h} \mathrm{com}$ pared to that at $30 \mathrm{~km} / \mathrm{h}$.

\begin{abstract}
Transport noise is a serious problem in cities and has a negative impact on both health and economics. In addition to the aforementioned unnoticed health effects, traffic noise has also been identified as one of the leading causes of sleep disorders, annoyance and negative cardiovascular effects. This research consists of three parts: part one involves onsite measurements of traffic noise in Trakai town; part two simulates traffic noise at different average vehicle speeds; part three assesses the number of people affected by traffic noise. The carried-out simulation has demonstrated that the noise level changes very slightly at different average vehicle speeds. It should be noticed that more noise is generated at average vehicle speed of $30 \mathrm{~km} / \mathrm{h}$ rather than at $50 \mathrm{~km} / \mathrm{h}$. The assessment of the annoyance level has disclosed that an average vehicle speed of $30 \mathrm{~km} / \mathrm{h}$ should cause the highest level of annoyance (highest $-26.8 \%$ ).
\end{abstract}

Keywords: environmental impact assessment, noise pollution, noise annoyance, environmental noise pollution.

\section{Introduction}

Environmental noise is the sound produced by transport, industry or appropriate recreational activity at the levels exceeding the intensity of the background noise required for personal daily activities, rest and sleep. Epidemiological studies have disclosed that persistent exposure to the high levels of environmental noise increases the risk of circulatory system diseases such as myocardial infarction. In this context, noise pollution is seen as an environmental protection problem and as a threat to public health. In addition, compared to other environmental risk factors like passive smoking, dioxins and benzene the magnitude of which tends to decrease, the impact of noise in Europe tends to rise (Ministry of Health of the Republic of Lithuania).
Noise damage to health is not limited to hearing loss. Prolonged exposure to intense noise develops functional disorders of the central and autonomic nervous systems. Even a relatively light noise of 60-70 decibels (dB) causes headache, dizziness, squeaking in ears, insomnia, impaired memory, distracted attention and diminished orientation. Under the influence of noise, physical and mental working capacity decreases by $10-25 \%$, the speed of human hearing and visual sensorimotor reactions deteriorates, vibrational sensitivity and the coordination of movements become reduced and the risk of industrial injuries increases (Vilnius environment).

Data from numerous studies confirm the link between environmental noise and deteriorating human health. Noise has been found to activate the sympathetic

*Corresponding author. E-mail: andrej.naimusin@vilniustech.lt 
and endocrine systems. Noise acts on the body directly through the connections between two neurons-synapses, pituitary glands and the hypothalamic system. The body is indirectly emotionally affected by noise through the cerebral cortex and subcortical structures (Spreng, 2000).

In addition to the aforementioned unnoticed health effects, traffic noise has also been identified as one of the leading causes of sleep disorders (de Kluizenaar et al., 2009), annoyance and negative cardiovascular effects (Fredianelli et al., 2019). Moreover, environmental noise may have an effect on sleep by increasing sleep time, stimulating awakenings, excitations and body movements thus reducing the overall amount and quality of sleep (Joost et al., 2018). People perceive, appreciate, and respond to external sounds even while sleeping (Dang-Vu et al., 2010; Basner et al., 2014). Besides, the unconscious activation of the autonomic nervous system during sleep occurs without cortical (cognitive) control due to the direct interaction of the auditory nerve and higher structures of the central nervous system (European Environment Agency [EEA], 2010). Thus, continuous exposure to noise irritates the central nervous system causing a stressful state. This can lead to the increased blood pressure and viscosity. Under effect of blood lipids, blood glucose may rise (Babisch et al., 2001). Researchers have found that noise-induced stress may form other diseases such as myocardial infarction and hypertension (Aydin \& Kaltenbach, 2007; de Kluizenaar et al., 2007; Jarup et al., 2008), arteriosclerosis or ischemic heart disease (Babisch et al., 2001).

The World Health Organization (WHO) provides that the A-weighted sound pressure level (LAeq) averaging at 50-55 dBA can cause moderate to severe annoyance in residential areas over a period of 16 hours, whereas noise levels exceeding 70 to $100 \mathrm{dBA}$ can result in permanent hearing loss and an increase in cardiovascular mortality and morbidity (World Health Orgnisation [WHO], 2011). Several studies have revealed a link between the impact of road traffic noise and the increased numbers of cardiovascular diseases (Recio et al., 2018), systolic blood pressure levels (Enoksson Wallas et al., 2019) and body mass index in young children (Enoksson Wallas et al., 2019). Although road traffic management systems have been improved in most European countries, it is estimated that the average day-evening-night noise level $\left(L_{d e n}\right)$ of more than 100 million people across the EU-33 made $\geq 55 \mathrm{dBA}$ (EEA, 2018).

Transport-induced noise is a serious problem in cities and has a negative impact on both health and economics. Reducing the mean noise level by $1 \mathrm{~dB}(\mathrm{~A})$ has been found to increase the value of housing by $0.5-1 \%$ on average (Navrud, 2002; Sælensminde \& Veisten, 2005). Traffic noise often exceeds the established limits in the cities crossed by trunk roads with high heavy traffic intensity. Even noise below $40 \mathrm{~dB}(\mathrm{~A})$ has been discovered to cause human complaints. $45 \mathrm{~dB}(\mathrm{~A})$ noise at night produces sleep disturbances. As early as 1999, the WHO established a correlation between long-term 67-70 $\mathrm{dB}(\mathrm{A})$ noise and hypertension (Berglund et al., 1999). Recent studies have shown that $50 \mathrm{~dB}(\mathrm{~A})$ noise levels at night may also increase the risk of myocardial infarction by chronically elevating the production of corticosteroid hormone-cortisol synthesized in the adrenal cortex (Maschke, 2003; Franssen et al., 2004).

The most commonly used assessment of noise pollution in the residential area is limited to the identification of a quantitative indicator applying numerical simulation programs and mapping, including environmental sites of interest, noise sources and the distribution of noise levels from residential areas (Directive 2002/49/EC, 2002). As for the use of information contained in the noise map to propose actions that would improve the current situation, only calculation methods allow evaluating the effectiveness of the proposed actions. However, nothing but on-site measurements provide a proper and accurate knowledge of the effectiveness of the noise abatement action plan. In order to assess the impact of noise levels on human health, the continuous monitoring of traffic noise levels is required thus announcing the results of strategic noise mapping and designing the updated noise abatement measures in response to the increased noise levels. To reduce noise in resort towns, similarly to the above introduced this case, average vehicle speed is often lowered, which is an issue of degrading noise level investigated in this paper.

\section{Methodology}

Strategic noise mapping consists of two parts: determining noise propagation in the investigated area and estimating the number of people exposed to the relevant noise level.

To determine noise propagation, long-term noise level measurements or calculations employing specific software are performed. In this case, computer simulation is more appropriate because it allows creating various situations, establishing the effectiveness of the anticipated noise reduction measures or, for example, presents the expected situation affected by permanently increasing traffic intensity.

Mapping employs CadnaA Environmental Noise Prediction Software used for simulating noise emission. CadnaA is the leading software for noise level calculation, presentation, assessment and forecasting. Simulation covers the processes of loading objects, data entry and calculation. Data can be entered using a keyboard, scanner and paper or digital plans in 15 different formats. CadnaA software assists in developing the projects of varying sizes. There is actually no software limitation on the number of objects (noise sources, roads, buildings, etc.) (DataKustik, 2016).

CadnaA software calculates noise levels at all locations and different points in both the horizontal and vertical plane. For simulating noise emission, the required national or international standards are selected. Certain specific noise sources like roads, railways or airports are calculated using the set values of technical parameters. Data can be presented in tabular form and displayed on horizontal noise maps or building noise maps (DataKustik, 2016). 
The conducted research consists of three parts: part one involves on-site measurements of traffic noise in Trakai town; part two simulates traffic noise at different average vehicle speeds; part three assesses the number of people affected by traffic noise with reference to standard LST ISO 1996-1.

First, measurements were carried out in Trakai area and covered the central part of the town counting the majority of residents and the high intensity of traffic. Noise levels were measured at the busiest streets. To accurately estimate traffic flows at different times of the day, measurements were performed during the day $(7 \mathrm{am}-7 \mathrm{pm})$, in the evening $(7 \mathrm{pm}-10 \mathrm{pm})$ and at night $(10 \mathrm{pm}-7 \mathrm{am})$. Measuring noise levels covered 15 minutes at each location with counting the volume of light and heavy transport. Class-1 precision sound analyser Bruel and Kjaer 2260 made in Denmark was used for noise measurements. The employed equipment measured parameters for equivalent and broadband noise and recorded noise ranging from $6.3 \mathrm{~Hz}$ to $20 \mathrm{kHz}$. Relative measurement error made $\pm 1.5 \%$. Measurements were taken at a height of 4 meters.

To assess the collected data, on-site measurements were included in the simulations of traffic noise at different average vehicle speeds. Simulated parameter $L_{d e n}$ is an indicator for determining the day-evening-night noise level and an indicator for general noise-induced annoyance. The day-evening-night noise level $\left(L_{d e n}\right)$ is measured in decibels ( $\mathrm{dBA})$ and calculated in line to the below formula:

$$
L_{\text {den }}=10 \lg \frac{1}{24}\left(12 \cdot 10^{\frac{L_{\text {day }}}{10}}+4 \cdot 10^{\frac{L_{\text {evening }}+5}{10}}+8 \cdot 10^{\frac{L_{\text {night }}+10}{10}}\right)
$$

(ISO 1991-1:2016),

where: $L_{\text {day }}$ (indicator for the day noise level) - the indicator for noise-induced annoyance during the day, i.e.

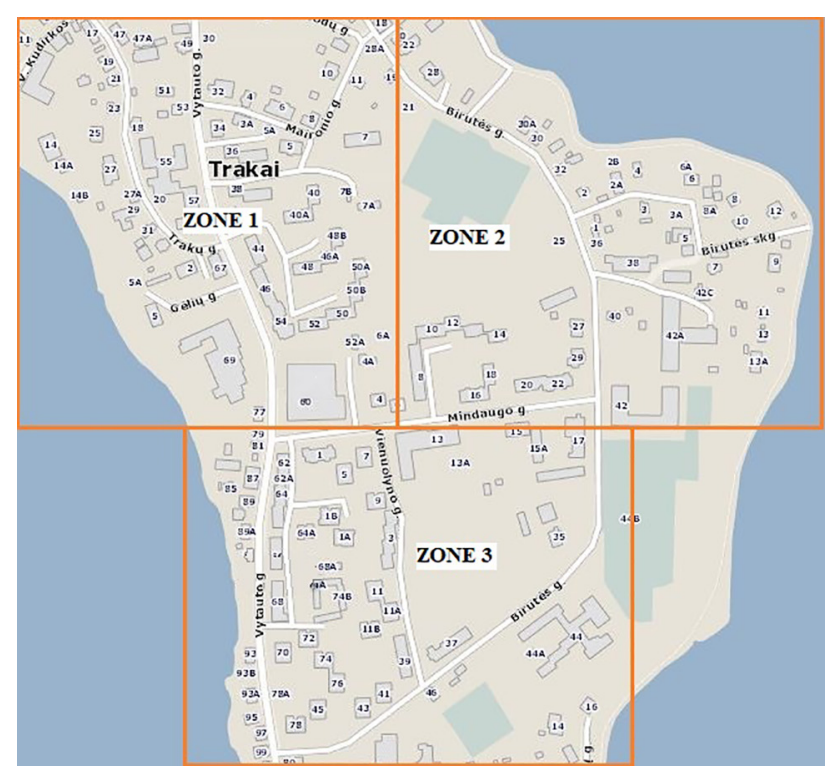

Figure 1. The zones of the central part of the town the long-term average A-weighted noise level during the day determined for a period of one year as defined in ISO 1991-1:2016; $L_{\text {evening }}$ (indicator for the evening noise level) - the indicator for noise-induced annoyance in the evening, i.e. the long-term average A-weighted noise level in the evening determined for a period of one year as defined in ISO 1996-1:2016; $L_{\text {night }}$ (indicator for the night level) - the indicator for noise-induced sleep disturbance at night, i.e. the long-term average A-weighted noise level at night determined for a period of one year as defined in ISO 1996-1:2016.

Noise simulation was performed in the central part of the town, including the main Vytauto, Birutès and Traku streets. The central part of the town was divided into three smaller zones (Figure 1).

For noise simulation, 3 different zones were selected. Zone one characterizes the central part of the town generating the highest traffic flow volumes and is dominated by low-rise construction houses. Zone two covers a quieter part of the town producing lower traffic flow volumes and is dominated by private 1-2 storey houses. Zone three comprises the most populated part of the town dominated by high-rise buildings.

To estimate traffic noise emission at different average vehicle speeds, 4 different simulations were performed selecting various rates of traffic flow. The idea originated from decreasing average vehicle speed that should also reduce the noise level caused by transport. Simulations were performed at the average vehicle speeds of $30 \mathrm{~km} / \mathrm{h}$, $40 \mathrm{~km} / \mathrm{h}, 50 \mathrm{~km} / \mathrm{h}$ and $60 \mathrm{~km} / \mathrm{h}$.

The last part of the study looked at the impact of traffic on people. Based on standard LST ISO 1996-1:2016, the level of traffic noise-induced annoyance $P_{H A}$ was assessed. $P_{H A}$ is designed to estimate the percentage level of noiseinduced annoyance with reference to the indicator for the day-evening-night noise level and considering the level of community tolerance to noise. The indicator is calculated in consonance to the formula:

$$
P_{H A}=100 e^{-\left(\frac{1}{10^{0.1\left(L_{d e n}-73.6 \mathrm{~dB}\right.}}\right)^{0.3}}
$$

(ISO 1996-1:2016),

where: $L_{d e n}$ - indicator for the day-evening-night noise level, $\mathrm{dB}$.

The indicator is determined in line to standard ISO 1996-1:2016 and in consonance with the indicator for the day-evening-night noise level $\left(L_{d e n}\right)$. The method is applied by surveying respondents and estimating the percentage of the noise-induced annoyance level under an appropriate indicator for the day-evening-night noise level $L_{\text {den }}$ representing a hypothetical average of people in a given community severely exposed to a certain level of noise (Fidell et al., 2011). Figure 2 shows the distribution of $P_{H A}$ values at different values of $L_{d e n}$. The $\mathrm{X}$ axis shows $L_{d e n}$ values, and $Y$ refers to $P_{H A}$ values. The solid line shows the mean value of $P_{H A}$ for how strongly people are annoyed by the generated noise. The dotted line points to the range of $P_{H A}$ values by considering the $95 \%$ confidence interval. 


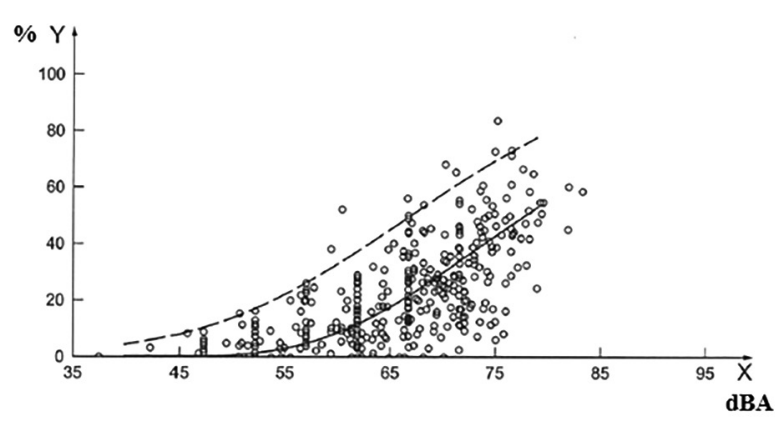

Figure 2. Chart of the distribution of the noise-induced annoyance level under different values of $L_{d e n}$

(ISO 1996-1:2016)

\section{Results}

\subsection{The analysis of noise level distribution in an established area}

Figure 3 shows the spread of the indicator for the dayevening-night noise level $\left(L_{d e n}\right)$ in Zone 1 simulating traffic flows rates of $30,40,50$ and $60 \mathrm{~km} / \mathrm{h}$. The completed simulation demonstrated that traffic noise modelled at $30 \mathrm{~km} / \mathrm{h}$ showed fluctuations in $L_{d e n}$ ranging from $58 \mathrm{~dB}$ to $63 \mathrm{~dB}$ in the area next to Traku Street. The noise level of the area next to Vytauto Street was even higher reaching between 64 and $70 \mathrm{~dB}$. Noise emission decreased moving away from the main streets. The noise level made $40-50 \mathrm{~dB}$ in the areas further from the street. The completed simulation disclosed that traffic noise modelled at $40 \mathrm{~km} / \mathrm{h}$ ranged from 60 to $62 \mathrm{~dB}$ in the area next to Traku Street and from 64 to $69 \mathrm{~dB}$ - in the area next to Vytauto Street. Similar data were obtained under average vehicle speeds of 50 and $60 \mathrm{~km} / \mathrm{h}$. In the first case, the noise level fluctuated from 58 to $62 \mathrm{~dB}$ in the area next to Traku Street and from 63 to $69 \mathrm{~dB}$ - in the area next to Vytauto Street. At an average vehicle speed of $60 \mathrm{~km} / \mathrm{h}$, the noise level ranged from 59 to $64 \mathrm{~dB}$ in the area next to Traku Street and from 64 to $70 \mathrm{~dB}$ - in the area next to Vytauto Street. In all cases, the noise level decreased moving away from the street thus reaching $40-50 \mathrm{~dB}$ in more remote areas. Based on the results obtained, vehicle engines make the biggest impact on noise at an average vehicle speed of $30 \mathrm{~km} / \mathrm{h}$ which decreases along with an increase in speed. At an average vehicle speed of $60 \mathrm{~km} / \mathrm{h}$, noise emission is caused by vehicle aerodynamics and tire noise.

Population annoyance $P_{H A}$ was calculated in line to Formula 2 and with reference to the indicator for the dayevening-night noise level. The obtained results are shown in the Table 1. It was found that the annoyance level under an average vehicle speed of $30 \mathrm{~km} / \mathrm{h}$ calculated for Vytauto Street in Trakai reached $15.7-26.8 \%$ and 5.7 to $11.6 \%$ - in the area next to Traku Street. The completed simulation demonstrated that an increasing average vehicle speed led to a drop in engine-produced noise thus decreasing environmental noise and the annoyance level. $P_{H A}$ values determined for Vytauto Street at the average vehicle speeds of 40 and $50 \mathrm{~km} / \mathrm{h}$ fluctuated from 14.0 to 24.6 and from 13.6 to $24.1 \%$ respectively. The values of average vehicle speeds of 40 and $50 \mathrm{~km} / \mathrm{h}$ on Birutes street ranged from 13.6 to 24.1 and from 5.9 to $11.4 \%$ respectively. Under an average vehicle speed of $60 \mathrm{~km} / \mathrm{h}, L_{\text {den }}$ values increased again and resulted in the rising values of $P_{H A}$ ranging from 15.1 to $26.0 \%$ on Vytauto Street and from 7.5 to $13.8 \%-$ on Trakų Street.

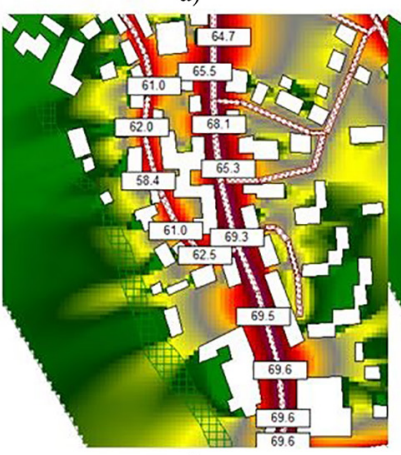

c) b)

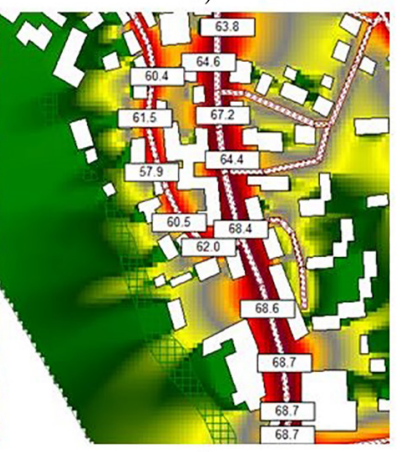

d)

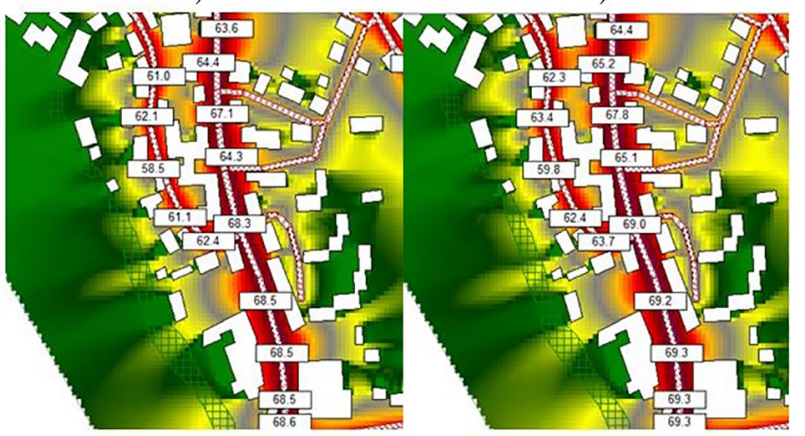

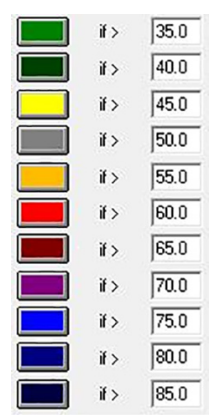


Table 1. Dependency of the population annoyance level in Zone 1 from vehicle speed

\begin{tabular}{|l|c|c|c|c|}
\hline \multicolumn{1}{|c|}{$\begin{array}{c}\text { Assessed } \\
\text { site }\end{array}$} & $\begin{array}{c}\text { Average } \\
\text { vehicle } \\
\text { speed, } \\
\mathrm{km} / \mathrm{h}\end{array}$ & $L_{\text {den }}, \mathrm{dB}$ & $\begin{array}{c}\text { Annoyance } \\
\text { level } P_{H A}, \\
\%\end{array}$ & $\begin{array}{c}95 \% \\
\text { confidence } \\
\text { interval, \% }\end{array}$ \\
\hline $\begin{array}{l}\text { Next to } \\
\text { Vytauto str. }\end{array}$ & 30 & $64.7-69.6$ & $15.7-26.8$ & $43.2-55.4$ \\
\hline $\begin{array}{l}\text { Next to } \\
\text { Vytauto str. }\end{array}$ & 40 & $63.8-68.7$ & $14.0-24.6$ & $40.8-3.0$ \\
\hline $\begin{array}{l}\text { Next to } \\
\text { Vytauto str. }\end{array}$ & 50 & $63.6-68.5$ & $13.6-24.1$ & $40.8-53.0$ \\
\hline $\begin{array}{l}\text { Next to } \\
\text { Vytauto str. }\end{array}$ & 60 & $64.4-69.3$ & $15.1-26.0$ & $40.8-53.0$ \\
\hline $\begin{array}{l}\text { Next to } \\
\text { Trakų str. }\end{array}$ & 30 & $58.4-62.5$ & $5.7-11.6$ & $27.5-38.5$ \\
\hline $\begin{array}{l}\text { Next to } \\
\text { Trakų str. }\end{array}$ & 40 & $57.9-62.0$ & $5.2-10.8$ & $27.5-36.2$ \\
\hline $\begin{array}{l}\text { Next to } \\
\text { Trakų str. }\end{array}$ & 50 & $58.5-62.4$ & $5.9-11.4$ & $29.5-36.2$ \\
\hline $\begin{array}{l}\text { Next to } \\
\text { Traku str. }\end{array}$ & 60 & $59.8-63.7$ & $7.5-13.8$ & $31.7-40.8$ \\
\hline
\end{tabular}

Figure 4 shows the equivalent noise level in Zone 2, including Birutès and Mindaugo streets, simulating average vehicle speeds of $30,40,50$ and $60 \mathrm{~km} / \mathrm{h}$. The completed simulation determined that under an average vehicle speed of $30 \mathrm{~km} / \mathrm{h}$ the noise generated in the area next to Mindaugo Street made 58-60 dB. The noise level of the area next to Birutes Street was higher and ranged from 59 to $64 \mathrm{~dB}$. The simulation of noise emission under an average vehicle speed of $40 \mathrm{~km} / \mathrm{h}$ showed variations in the noise level ranging from 57 to $60 \mathrm{~dB}$ in the area next to Mindaugo Street, and from 58 to $63 \mathrm{~dB}$ - in the area next to Birutess Street. Similar data were obtained at an average vehicle speed of $50 \mathrm{~km} / \mathrm{h}$. The noise level near Mindaugo Street varied from 57 to $63 \mathrm{~dB}$ and that in the area next to Birutes Street - from 58 to $63 \mathrm{~dB}$. At an average vehicle speed of $60 \mathrm{~km} / \mathrm{h}$, the noise level near Mindaugo Street ranged from 58 to $60 \mathrm{~dB}$, and that in the area next to Birutes Street fluctuated from 58 to $63 \mathrm{~dB}$. In all cases, the noise level decreases moving away from the street thus reaching 40-50 dB in the remote areas of the streets. Compared to Zone 1, noise levels are lower in this area due to a smaller traffic flow volume passing through and highly reduced numbers of heavy transport.

The $P_{H A}$ values examined considering $L_{d e n}$ values showed that $L_{d e n}$ values were highest due to the noise generated by the vehicle engine under an average vehicle speed of $30 \mathrm{~km} / \mathrm{h}$, which resulted in the highest level of annoyance under the values fluctuating from 6.9 to 14.2\%. The obtained results are shown in the Table 2. An increase in average vehicle speed reduced the noise level, and therefore the annoyance level varied from 5.7 to $12.1 \%$ under an average vehicle speed of $40 \mathrm{~km} / \mathrm{h}$ in the area next to Birutes Street. At an average vehicle speed of $50 \mathrm{~km} / \mathrm{h}, P_{H A}$ values ranged from 5.1 to $11.3 \%$. Under an average vehicle speed of $60 \mathrm{~km} / \mathrm{h}$, the noise level started increasing, and therefore the annoyance level fluctuated from $5.6-12.0 \%$. The same trend was observed on Mindaugo Street, where the noise produced by the engines of slow-moving vehicles had the greatest impact on noise emission. a)

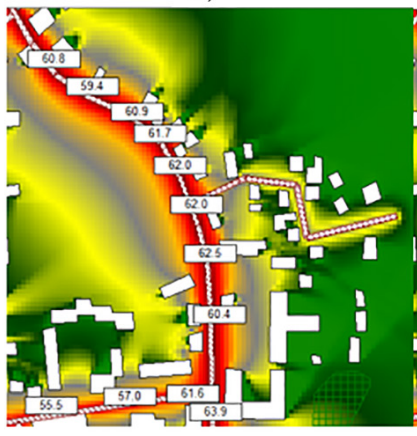

c)

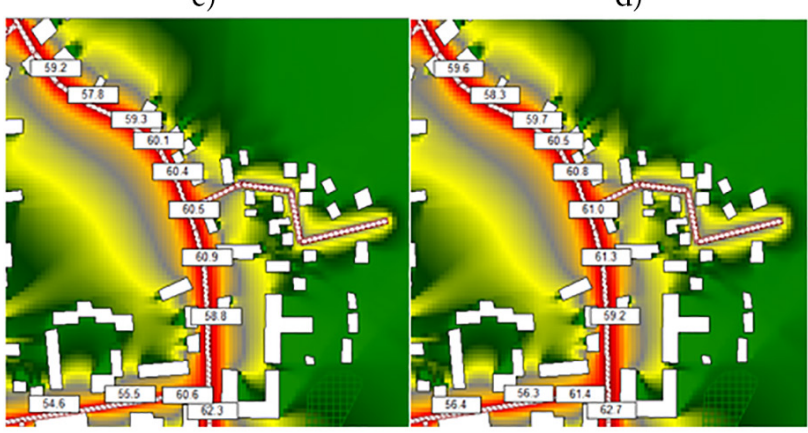

b)

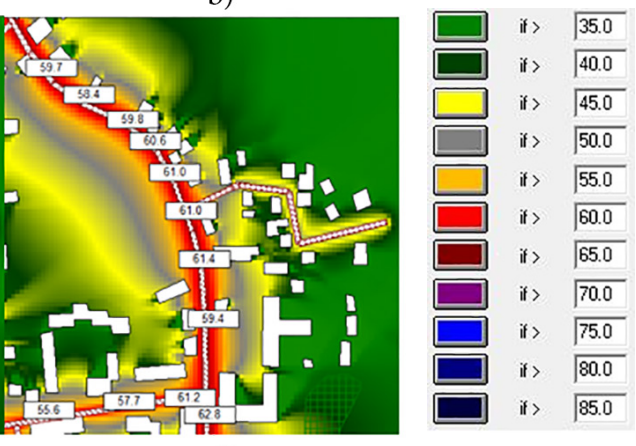

d) 
Table 2. Dependency of the population annoyance level in Zone 2 from vehicle speed

\begin{tabular}{|l|c|c|c|c|}
\hline Assessed site & $\begin{array}{c}\text { Average } \\
\text { vehicle } \\
\text { speed, } \\
\mathrm{km} / \mathrm{h}\end{array}$ & $L_{\text {den }} \mathrm{dB}$ & $\begin{array}{c}\text { Annoyance } \\
\text { level } P_{H A}, \\
\%\end{array}$ & $\begin{array}{c}95 \% \\
\text { confidence } \\
\text { interval, \% }\end{array}$ \\
\hline $\begin{array}{l}\text { Next to } \\
\text { Birutès str. }\end{array}$ & 30 & $59.4-63.9$ & $6.9-14.2$ & $29.5-40.8$ \\
\hline $\begin{array}{l}\text { Next to } \\
\text { Birutès str. }\end{array}$ & 40 & $58.4-62.8$ & $5.7-12.1$ & $27.5-38.5$ \\
\hline $\begin{array}{l}\text { Next to } \\
\text { Birutės str. }\end{array}$ & 50 & $57.8-62.3$ & $5.1-11.3$ & $27.5-36.2$ \\
\hline $\begin{array}{l}\text { Next to } \\
\text { Birutès str. }\end{array}$ & 60 & $58.3-62.7$ & $5.6-12.0$ & $27.5-38.5$ \\
\hline $\begin{array}{l}\text { Next to Min- } \\
\text { daugo str. }\end{array}$ & 30 & $55.5-61.6$ & $3.0-10.1$ & $23.5-36.2$ \\
\hline $\begin{array}{l}\text { Next to Min- } \\
\text { daugo str. }\end{array}$ & 40 & $55.6-61.2$ & $3.1-9.5$ & $23.5-33.9$ \\
\hline $\begin{array}{l}\text { Next to Min- } \\
\text { daugo str. }\end{array}$ & 50 & $54.6-60.6$ & $2.4-8.6$ & $21.7-33.9$ \\
\hline $\begin{array}{l}\text { Next to Min- } \\
\text { daugo str. }\end{array}$ & 60 & $56.4-61.4$ & $3.6-9.8$ & $23.5-33.9$ \\
\hline
\end{tabular}

Figure 5 shows the equivalent noise level in Zone 3, including Birutès and Vytauto streets, simulating traffic flows rates of $30,40,50$ and $60 \mathrm{~km} / \mathrm{h}$. The completed simulation of the noise generated by traffic flows determined that under an average vehicle speed of $30 \mathrm{~km} / \mathrm{h}$ transportinducted noise ranged from 61 to $65 \mathrm{~dB}$ in the area next to Birutes Street. The noise level of the area next to Vytauto Street was higher making 69-70 dB. The simulation of noise emission under an average vehicle speed of $40 \mathrm{~km} / \mathrm{h}$ disclosed variations in the noise level ranging from 60 to $64 \mathrm{~dB}$ in the area next to Birutes Street, and from 68 to $59 \mathrm{~dB}$ - in the area next to $\mathrm{Vy}$ tauto Street. At an average vehicle speed of $50 \mathrm{~km} / \mathrm{h}$, the noise level of Birutes Street varied from 60 to 63 $\mathrm{dB}$ while that of Vytautas Street reached 68-69 dB. The simulated average vehicle speed of $60 \mathrm{~km} / \mathrm{h}$ in the area next to Birutes Street recorded the noise level ranging between 60 and $64 \mathrm{~dB}$, while that established in the area next to Vytautas Street reached 69-70 dB. In all cases, the noise level decreases moving away from the street and ranges between 40 and $55 \mathrm{~dB}$ in the remote areas of the busy streets. A comparison between Zone 1 and Zone 2 shows that noise levels are highest in this area, as this particular section of the town faces the highest traffic flow moving mainly on Vytauto Street and a large volume of heavy traffic in the total flow. In addition, this area is occupied by high-rise buildings erected close to the road, which reflects vehicle-reduced sound thus further enhancing the noise level.

The analysis of the annoyance level in Zone 3 next to Birutes and Vytauto streets showed that $L_{d e n}$ values were highest at an average vehicle speed of $30 \mathrm{~km} / \mathrm{h}$ compared to the average vehicle speeds of 40,50 and $60 \mathrm{~km} / \mathrm{h}$. The obtained results are shown in the Table 3 . In that case, $P_{H A}$ fluctuated between 10.0 and $16.1 \%$ in the area next to Birutes Street and between 26.3 and $27.5 \%$ - in the area next to Vytauto Street. Likewise in the other areas, the noise level decreased slightly along with an increase in the average vehicle speeds of 40 and $50 \mathrm{~km} / \mathrm{h}$, because the noise produced by the vehicle engine was lower due to higher revolutions. Therefore, the annoyance level at respective average vehicle speeds ranged between 8.3 and 14.2 and between 7.7 and 13.0\% a)

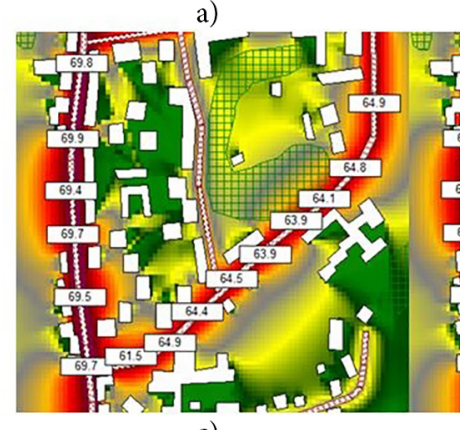

c) b)

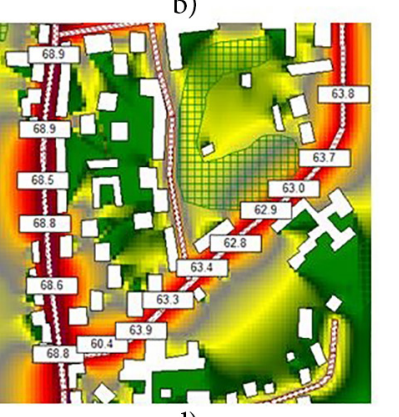

d)

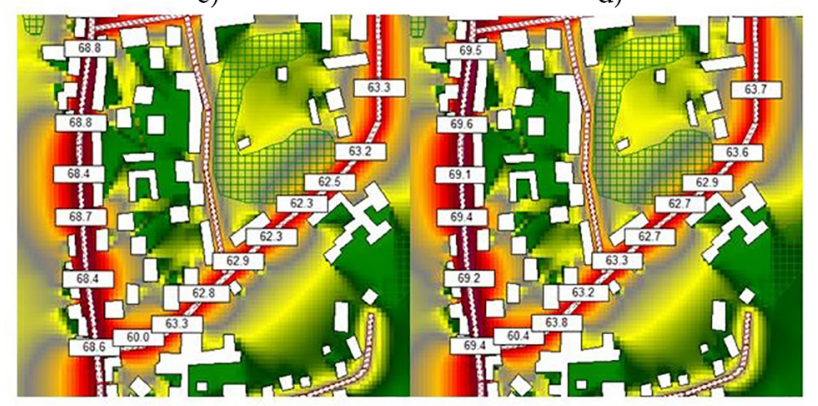

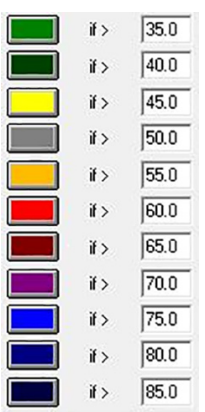

if $\longdiv { 8 5 . 0 }$ 
Table 3. Dependency of the population annoyance level in Zone 3 from vehicle speed

\begin{tabular}{|l|c|c|c|c|}
\hline Assessed site & $\begin{array}{c}\text { Average } \\
\text { vehicle } \\
\text { speed, } \\
\mathrm{km} / \mathrm{h}\end{array}$ & $L_{\text {den }}, \mathrm{dB}$ & $\begin{array}{c}\text { Annoy- } \\
\text { ance level } \\
P_{H A}, \%\end{array}$ & $\begin{array}{c}95 \% \text { confi- } \\
\text { dence } \\
\text { interval, } \%\end{array}$ \\
\hline $\begin{array}{l}\text { Next to } \\
\text { Birutès str. }\end{array}$ & 30 & $61.5-64.9$ & $10.0-16.1$ & $36.2-43.2$ \\
\hline $\begin{array}{l}\text { Next to } \\
\text { Birutès str. }\end{array}$ & 40 & $60.4-63.9$ & $8.3-14.2$ & $31.7-40.8$ \\
\hline $\begin{array}{l}\text { Next to } \\
\text { Birutès str. }\end{array}$ & 50 & $60.0-63.3$ & $7.7-13.0$ & $31.7-38.5$ \\
\hline $\begin{array}{l}\text { Next to } \\
\text { Birutès str. }\end{array}$ & 60 & $60.4-63.8$ & $8.3-14.0$ & $31.7-40.8$ \\
\hline $\begin{array}{l}\text { Next to } \\
\text { Vytauto str. }\end{array}$ & 30 & $69.4-69.9$ & $26.3-27.5$ & $53.0-55.4$ \\
\hline $\begin{array}{l}\text { Next to } \\
\text { Vytauto str. }\end{array}$ & 40 & $68.5-68.9$ & $24.1-25.1$ & $53.0-53.0$ \\
\hline $\begin{array}{l}\text { Next to } \\
\text { Vytauto str. }\end{array}$ & 50 & $68.4-68.8$ & $23.9-24.8$ & $50.6-53.0$ \\
\hline $\begin{array}{l}\text { Next to } \\
\text { Vytauto str. }\end{array}$ & 60 & $69.1-69.6$ & $25.5-26.8$ & $53.0-55.4$ \\
\hline
\end{tabular}

in the area next to Birutes Street. $P_{H A}$ values varied from 24.1 to 25.1 and from 23.9 to $24.8 \%$ respectively in the area next to Vytauto Street. At an average vehicle speed of $60 \mathrm{~km} / \mathrm{h}$, the annoyance level ranged between 8.3 and $14.0 \%$ in the area next to Birutes Street and from 25.5 to $26.8 \%$ in the area next to Vytauto Street.

\section{Discussion}

The carried-out simulation has demonstrated that the noise level changes very slightly at different average vehicle speeds. It should be noticed that more noise is generated at an average vehicle speed of $30 \mathrm{~km} / \mathrm{h}$ rather than at $50 \mathrm{~km} / \mathrm{h}$. The obtained results show that the noise level is sufficiently high under an average vehicle speed of $30 \mathrm{~km} / \mathrm{h}$. In contrast to the assumptions made before studies, a rise in traffic flow decreases the noise level that is lower at 40 and $50 \mathrm{~km} / \mathrm{h}$ compared to that at $30 \mathrm{~km} / \mathrm{h}$. However, at an average vehicle speed of $60 \mathrm{~km} / \mathrm{h}$, the noise level rises again and reaches very similar values as in the case of $30 \mathrm{~km} / \mathrm{h}$. Thus, it is supposed a running vehicle engine is the main source of noise in slow-moving vehicles because higher revolutions of the engine are observed at the slow motion of vehicles, which results in higher noise levels.

As Cesar Asensio et al. wrote in their paper there are many variables that we could list, from the type of vehicle or tire to the state of maintenance of the exhaust, the acceleration noise or horn sound, could affect measured values on site (Asensio et al., 2021). So, a rise in an average vehicle speed of up to $60 \mathrm{~km} / \mathrm{h}$ shows that vehicle tires are the main source of noise that can also be affected by vehicle aerodynamics. Therefore, it is assumed that a further rise in average vehicle speed will elevate the noise level, but simulating such situation is no longer relevant. Hence, the volume of traffic flow, particularly the percentage of heavy transport in the total traffic, has the greatest impact on transport-induced noise.

\section{Conclusions}

1. The assessment of the annoyance level has disclosed that an average vehicle speed of $30 \mathrm{~km} / \mathrm{h}$ should cause the highest level of annoyance, because this indicator is directly dependent on $L_{d e n}$ values. The assessment of optimal average vehicle speed in Trakai suggests a rate of $40-50 \mathrm{~km} / \mathrm{h}$, which causes minor problems for people's quality of life. In this case, engine-induced noise is lower due to higher revolutions, and an increase in average vehicle speed generates noise due to the aerodynamics of the vehicle and noise made by tires.

2. Carried-out noise simulation in Zone 1 shows that $L_{\text {den }}$ is ranging from $58 \mathrm{~dB}$ to $63 \mathrm{~dB}$ in the area next to Traku Street and from 64 to $70 \mathrm{~dB}$ on Vytauto Street while traffic noise was modelled at $30 \mathrm{~km} / \mathrm{h}$ average speed. It was found that in Zone 1 the annoyance level under an average vehicle speed of $30 \mathrm{~km} / \mathrm{h}$ calculated for Vytauto Street reached $15.7-26.8 \%$ and 5.7 to $11.6 \%$ - in the area next to Trakų Street.

3. Carried-out noise simulation in Zone 2 shows that under an average vehicle speed of $30 \mathrm{~km} / \mathrm{h}$ the noise generated in the area next to Mindaugo Street made 58-60 dB and noise level of the area next to Birutes Street was higher and ranged from 59 to $64 \mathrm{~dB}$. the noise generated by the vehicle engine under an average vehicle speed of $30 \mathrm{~km} / \mathrm{h}$, which resulted in the highest level of annoyance under the values fluctuating from 6.9 to $14.2 \%$.

4. Carried-out noise simulation in Zone 3 shows that under an average vehicle speed of $30 \mathrm{~km} / \mathrm{h}$ transport-inducted noise ranged from 61 to $65 \mathrm{~dB}$ in the area next to Birutes Street. The noise level of the area next to Vytauto Street was higher making 69-70 dB. $P_{H A}$ fluctuated between 10.0 and $16.1 \%$ in the area next to Birutes Street and between 26.3 and $27.5 \%$ - in the area next to Vytauto Street.

\section{References}

Asensio, C., Pavón, I., Ramos, C., López, J. M., Pamiés, Y., Moreno, D., \& de Arcas, G. (2021). Estimation of the noise emissions generated by a single vehicle while driving. Transportation Research Part D: Transport and Environment, 95, 102865. https://doi.org/10.1016/j.trd.2021.102865

Aydin, Y., \& Kaltenbach, M. (2007). Noise perception,heart rate andbloodpressure in relation to aircraft noise in the vicinity of the Frankfurt airport. Clinical Research in Cardiology, 96(6), 347-358. https://doi.org/10.1007/s00392-007-0507-y

Babisch, W., Fromme, H., Beyer, A., \& Ising, H. (2001). Increased catecholamine levls in urine in subjects exposed to road traffic noise. The role of stress hormones in noise research. Environmental International, 26(7-8), 475-481. https://doi.org/10.1016/S0160-4120(01)00030-7

Basner, M., Babisch, W., Davis, A., Brink, M., Clark, C., Janssen, S., \& Stansfeld, S. (2014). Auditory and non-auditory 
effects of noise on health. Lancet, 383(9925), 1325-1332. https://doi.org/10.1016/S0140-6736(13)61613-X

Berglund, B., Lindvall, T., Schwela, D., \& Goh, K. T. (1999). Guidelines for community noise. World Health Organization.

Dang-Vu, T. T., McKinney, S. M., Buxton, O. M., Solet, J. M., \& Ellenbogen, J. M. (2010). Spontaneous brain rhythms predict sleep stability in the face of noise. Current Biology, 20(15), R626-R627. https://doi.org/10.1016/j.cub.2010.06.032

DataKustik. (2016). CadnaA handling and modelling. https:// www.datakustik.com/products/cadnaa/features/handlingand-modelling/

de Kluizenaar, Y., Gansevoort, R. T., Miedema, H. M. E., \& de Jong, P. E. (2007). Hypertension and road traffic noise exposure. Journal of Occupational and Environmental Medicine, 49(5), 484-492.

https://doi.org/10.1097/JOM.0b013e318058a9ff

de Kluizenaar, Y., Janssen, S. A., van Lenthe, F. J., Miedema, H. M., \& Mackenbach, J. P. (2009). Long-term road traffic noise exposure is associated with an increase in morning tiredness. The Journal of the Acoustical Society of America, 126(2), 626-633. https://doi.org/10.1121/1.3158834

Enoksson Wallas, A., Eriksson, C., Edstedt Bonamy, A.-K., Gruzieva, O., Kull, I., Ögren, M., Pyko, A., Sjöström, M., \& Pershagen, G. (2019). Traffic noise and other determinants of blood pressure in adolescence. International Journal of Hygiene and Environmental Health, 222(5), 824-830. https://doi.org/10.1016/j.ijheh.2019.04.012

European Environmental Agency. (2010). Good practice guide on noise exposure and potential health effects (EEA Technical report No. 11). Copenhagen.

European Environment Agency. (2018). Population exposure to environmental noise. EEA, Denmark.

European Parliament and Council of the European Union. (2002). Directive 2002/49/EC of the European Parliament and of the Council of 25 June 2002 relating to the assessment and management of environmental noise. https://eur-lex.europa. eu/LexUriServ/LexUriServ.do?uri=OJ:L:2002:189:0012:0025 :EN:PDF

Fidell, S., Mastre, V., Schomer, P., Berry, B., Gjestland, T., Vallet, M., \& Reid, T. (2011). A first-principles model for estimating the prevalence of annoyance with aircraft noise exposure. The Journal of the Acoustical Society of America, 130(2), 791-806.

Franssen, E. A., van Wiechen, C. M., Nagelkerke, N. J., \& Lebret, E. (2004). Aircraft noise around a large international air- port and its impact on general health and medication use. Occupational and Environmental Medicine, 61(5), 405-413. https://doi.org/10.1136/oem.2002.005488

Fredianelli, L., Carpita, S., \& Licitra, G. (2019). A procedure for deriving wind turbine noise limits by taking into account annoyance. Science of the Total Environment, 648, 728-736. https://doi.org/10.1016/j.scitotenv.2018.08.107

International Organization for Standardization.(2016). Acoustics - Description, measurement and assessment of environmental noise - Part 1: Basic quantities and assessment procedures (ISO 1996-1:2016). https://www.iso.org/standard/59765.html

Jarup, L., Babisch, W., Houthuijs, D., Pershagen, G., Katsouyanni, K., Cadum, E., Marie-Dudley, L., Savigny, P., Seiffert, I., Swart, W., Breugelmans, O., Bluhm, G., Selander, J., Haralabidis, A., Dimakopoulou, K., Sourtzi, P., Velonakis, M., \& Vigna-Taglianti, F. (2008). Hypertension and exposure to noise near airports: The HYENA study. Environmental Health Perspect, 116(3), 329-333. https://doi.org/10.1289/ehp.10775

Joost, S., Haba-Rubio, J., Himsl, R., Vollenweider, P., Preisig, M., Waeber, G., Marques-Vidal, P., Heinzer, R., \& Guessous, I. (2018). Spatial clusters of daytime sleepiness and association with nighttime noise levels in a Swiss general population (GeoHypnoLaus). International Journal of Hygiene and Environmental Health, 221(6), 951-957. https://doi.org/10.1016/j.ijheh.2018.05.004

Maschke, C. (2003). Stress hormone changes in persons exposed to simulated night noise. Noise Health, 5(17), 35-45.

Navrud, S. (2002). The state-of-the-art on economic valuation of noise (Final report to European Commission DG Environment). Department of Economics and Social Sciences.

Recio, A., Linares, C., \& Díaz, J. (2018). System dynamics for predicting the impact of traffic noise on cardiovascular mortality in Madrid. Environmental Research, 167, 499-505. https://doi.org/10.1016/j.envres.2018.07.021

Sælensminde, K., \& Veisten, K. (2005). Conversion of costs and benefits to monetary terms - input to cost-benefit analyses of measures to control road traffic noise SILVIA document SILVIA-TOI-003-03-WP3-310305. Sustainable Road Surfaces for Traffic Noise Control (SILVIA).

Spreng, M. (2000). Central nervous system activation by noise. Noise Health, 2(7), 49-58.

World Health Orgnisation. (2011). Burden of disease from environmental noise: Quantification of healthy life years lost in Europe. https://apps. who.int/iris/bitstream/handle/10665/326424/9789289002295eng.pdf? sequence $=1$ \&isAllowed $=y$ 